\section{Johns Hopkins as international host}

\section{Washington}

WITH funds from the Howard Hughes Institute (HHI), researchers at Johns Hopkins University (JHU) in Baltimore, Maryland, are planning an international network of databases to support the mapping and sequencing of the human genome. The selection of JHU as host to the first database in the network puts a question mark over the future of the human genome mapping library in New Haven, Connecticut, which is directed by Frank Ruddle of Yale University, and has been supported by the HHI since 1985. But Purnell Choppin, president of $\mathrm{HHI}$, said that researchers at JHU are also seeking federal funds and if they are successful the institute will not fund the database next year.

The new database at JHU, formally named the Genome Data Base (GDB), will provide access to primary data and literature citations, and daily updates of information generated by scientific workshops, the database's scientific editors and individual laboratories.

Users will also have access to OMIM, the on-line version of Mendelian Inheritance in Man, Victor McKusick's classic encyclopaedia of human genetic diseases. Peter Pearson, who worked at the University of Leiden in the Netherlands before he was hired by the HHI to be scientific director of the database, says that he was given a choice between Yale and JHU as the home of a new, more modern database, and that access to OMIM was one of the reasons he chose JHU. With access to both GDB and OMIM, users "will certainly get more for their money", he said. Other databases with which Pearson also hopes to forge links include the mouse genome database at Jackson Laboratory in Bar Harbor, Maine, and that at the Centre d'Etude du Polymorphisme Humain in Paris.

The second centre in the network will be created in London, with the collaboration of the Imperial Cancer Research Fund. Data from the GDB will be transferred at the international human gene mapping workshop in the United Kingdom, and at every subsequent workshop the data will be updated and transferred to a new centre. Eventually there will be an international network of human genome databases.

Kenneth Kidd of the school of medicine at Yale University, a consultant to the Yale database, says that it is trying to obtain funds from other sources, including the federal government, to replace the support from the HHI which this year was about $\$ 1.2$ million. The university was rejected as a candidate to host the new database amid complaints that the database there is in an outdated format, difficult to access and non-portable.

Christine McGourty

\title{
Japan presses on regardless
}

Tokyo

IN spite of the growing anti-nuclear, movement and the changing political environments, Japan is maintaining its commitment to expand nuclear power as its primary energy source, according to this year's white paper (policy document) on atomic energy, released last week by the Atomic Energy Commission (AEC).

Japan now has 37 commercial nuclear power plants in operation, supplying nearly 30 per cent of its electricity, and in its annual report two years ago the AEC outlined ambitious plans to increase that figure to 40 per cent by the year 2000 . But in the latest report, such optimistic projections are conspicuously absent. The AEC notes that nuclear power has suffered setbacks outside Japan: in the United States, no new plants have been brought into operation for over a decade, West Germany has cancelled plans to build a nuclear-fuel reprocessing plant, and Sweden, Austria and Italy have voted against nuclear power.

Nevertheless, the Japanese report concludes that nuclear power is still "steadily expanding" worldwide and will remain central to Japan's energy policy.

But within Japan, opposition to nuclear power is growing (see Nature 333, 199; $1988)$. In the past 18 months, the government and power industry has poured tens of millions of dollars into advertising campaigns, lectures and a telephone service to try to win back public support for nuclear power. But surveys earlier this year show that opponents of nuclear power outnumber supporters two to one (see Nature 337, $494 ; 1989)$.

The government faces two severe tests of its nuclear power policy in the near future. A huge commercial complex to enrich uranium, reprocess spent nuclear fuel, and store low-level radioactive waste is scheduled to begin operations in 1991 in Aomori Prefecture, on the northern tip of the main island of Japan, but local farmers vehemently oppose the plan.

And in 1992, Japan hopes to start taking shipments of plutonium from Britain and France. The plutonium is derived from spent nuclear fuel from Japanese reactors, and is intended for use in advanced thermal reactors; Japan's first prototype fastbreeder reactor should become operational in 1992. But plans to ship the plutonium by air have already been abandoned because of opposition in the US Congress.

The AEC and the Science and Technology Agency (STA), which oversees Japan's nuclear power research and development, want to construct a new ship, to be operated by the Maritime Safety Agency, for plutonium transportation. But some members of the ruling Liberal Democratic Party (LDP) insist that exist- ing ships of the Maritime Self-Defense Force should be used. However, despatch of these ships overseas is likely to cause public controversy, as it may violate military restrictions in Japan's post-war constitution. In addition, Japan has to face up to the problem of decommissioning nuclear reactors. Throughout the AEC report, nuclear power is referred to as "inexpensive" and "economical".

But the UK Central Electricity Generating Board, which has in the past promoted the low costs of nuclear power, had to admit at a recent public inquiry that the costs of decommissioning and waste disposal make nuclear power more expensive than coal power. This admission weighed heavily in the British decision two weeks ago to abandon plans to privatize the nuclear sector of the power industry (see Nature 342, 213; 1989).

However, British reactors are bulkier, older and more inefficient than their Japanese equivalents. Yukiko Araki, deputy director of STA's Office of Atomic Energy Policy Research, said at a briefing on the AEC report that decommissioning and waste disposal are expected to increase the cost of electricity from nuclear power plants in Japan only to $¥ 10$ ( 7 cents) per kilowatt hour from the present rate of $¥ 9$. The power industry recently established a fund derived from utility charges to cover the extra costs.

But finding a site for disposal of Japan's high-level waste is another headache for the government. Early plans for deep-sea disposal were abandoned because of objections from neighbouring Pacific island nations. A borehole survey of a site on Hokkaido, Japan's northern island, has been carried out and, says Araki, the government plans to bury high-level waste there at a depth of hundreds of metres. But Hokkaido residents oppose the plan and finding alternative sites will not be easy, especially because of the prevalence of volcanoes and earthquakes throughout Japan.

Finally, the recent rise in strength of the Japan Socialist Party (JSP), following a series of money and sex scandals that have forced the resignation of two prime ministers this year, has added a new political force to the fight against nuclear power.

The JSP has traditionally advocated the abolition of nuclear power, but now takes the more pragmatic position that it will not expand the industry if it gains power in the imminent general election.

Araki says that people in the industry do not now expect Japan to reach the commission's target of 40 per cent nuclear-power-derived electricity by 2000 , and that the Ministry of International Trade and Industry is working on new targets. 